\title{
Management of bacterial canker of tomato caused by Clavibecter michiganensis subsp. michiganensis (Smith and Davis et al.) using different antibiotics
}

\author{
Ammara Khalid, Raja Asad Ali Khan*, Musharaf Ahmad, Asad Ali, \\ Syed Sartaj Alam and Ishrat Naz \\ Department of Plant Pathology, The University of Agriculture Peshawar-Pakistan \\ *Corresponding author's email: raja.asad40@yahoo.com \\ Citation \\ Ammara Khalid, Raja Asad Ali Khan*, Musharaf Ahmad, Asad Ali, Syed Sartaj Alam and Ishrat Naz. Management \\ of bacterial canker of tomato caused by Clavibecter michiganensis subsp. michiganensis (Smith and Davis et al.) \\ using different antibiotics. Pure and Applied Biology. Vol. 8, Issue 2, pp1841-1849. \\ http://dx.doi.org/10.19045/bspab.2019.80128
}

\begin{tabular}{llll}
\hline \hline Received: 25/04/2019 & Revised: 24/06/2019 & Accepted: 27/06/2019 & Online First: 29/06/2019 \\
\hline \hline
\end{tabular}

\section{Abstract}

In an attempt to control bacterial canker of tomato, a very hard-to-control disease, both in-vitro and in-vivo studies were conducted using antibiotics alone or in combinations with other antibiotics and with copper oxychloride. Using paper disc diffusion assay and $50 \mathrm{ppm}-400 \mathrm{ppm}$ concentrations, tetracycline+streptomycin produced the largest inhibition zone $(22.8 \mathrm{~mm})$ followed by tetracycline alone (22.0) at highest concentration after $48 \mathrm{hrs}$ incubation. The result of antibiotic combination streptomycin and gentamicin were statistically at par with those of tetracycline+streptomycin combination. However, streptomycin alone proved to be ineffective. Antibiotic concentrations of $250 \mathrm{ppm}$ and higher were sufficient to inhibit the in-vitro bacterial growth. In case of screen-house studies, combination of tetracycline and copper oxychloride gave minimum \% disease severity (5.40\%), as compared to inoculated but untreated control in which case the $\%$ disease severity was $56.6 \%$. The same combination (i.e. tetracycline+copper oxychloride) also proved to be more effective than other treatments in term of enhancing yield per plant $(1147.7 \mathrm{~g})$, plant height $(102.0 \mathrm{~cm})$, plant dry weight $(130.8 \mathrm{~g})$ and other parameters. The better performance of this combination treatment could be attributed to its interactive effect. This study suggested that combination of antibiotics should be used for proper disease management and further combinations of different antibiotics in different concentrations should be evaluated.

Keywords: Antibiotics; Bacteria; Clavibecter; Tomato

Introduction

Tomato, Lycopersicon esculentum, belonging to family Solanaceae is a popular vegetable [1]. It is the second most consumed vegetable in the world behind potato. Tomato is an excellent source of phosphorus, iron and vitamin $\mathrm{A}, \mathrm{B}$ and $\mathrm{C}$. They also contain small amounts of the B 
complex vitamins; thiamin, niacin riboflavin [2].

Tomato fruit contain 93\% water which provides conducive environment to various microorganisms including bacterial canker pathogen. Bacterial canker has been a serious problem all over the world. The causal organism of bacterial canker is Clavibacter michiganensis subsp. michiganensis $(\mathrm{Cmm})$ [3].The color of the bacterial colonies when grow on nutrient agar medium could be yellow, white and pink with the most virulent forms being yellow and white [4]. On nutrient agar, the colonies are smooth but become butter like, with continued sub culturing, pale yellow becoming deeper yellow, cloudy and glistening [3]. Common name of the disease is bacterial canker. Other names used to describe bacterial canker include bird's eye spot, stem rot and stem canker. The first symptoms of bacterial canker are chlorosis (yellowing), curling and wilting of the leaflets, often on one side of the leaf. The affected leaflets become necrotic and dry but remain attached to the plant. Long brown strips may appear on stems and shoots. These strips dry and crack open to form cankers from which the disease gets its name [5]. The most distinctive symptoms of bacterial canker are fruit lesion called bird's eye lesion and the vascular discoloration at the junction between the stem and the petiole. At later stage, longitudinal cankerlike openings appear on stem, petiole and midrib resulting in stunting of plants. The bacterium is soil inhabitant and also remains in seed coat. Invasion of the cotyledons happens through stomata. The organism, after getting established in the phloem invades cortex and cause formation of lysogenous cavities [6].

Management of bacterial diseases depends mostly on "host resistance, sanitation (e.g., preventing the introduction of pathogens and removing diseased plants) and cultural practices (e.g., avoiding overhead irrigation and limiting nitrogen fertilization)". In some cases, chemical bactericides (e.g., copper compounds and antibiotics) and biological control agents are successfully integrated into the disease management program. Bacterial canker may be avoided by using certified plant material [7] or applying effective antibiotic or copper compounds in the greenhouse and the field [8]. Unfortunately no commercial varieties with resistance to $C$. michiganensis subsp. michiganensis have been developed to date [9].

Because of being systematic and effective, various antibiotics are used for control of many plants bacterial diseases. Antibiotics are produced by bacteria, fungi, actinomycetes and to a limited extent by other groups of microorganism [10]. Antibiotics are neither disinfectants nor antiseptic but they are selective antimicrobial agents applied to living tissue to kill or prevent the growth of susceptible microorganisms. The "selective action of antibiotics upon bacteria and other microorganisms" is known as the antibiotic spectrum. Some antibiotics are categorized as very narrow spectrum, whereas others have a wide range of activity. Some are active only against certain bacteria and not upon others, whereas some are active against fungi too. The most commonly used plant antibiotics are oxytetracycline, streptomycin, kasugamicine and gentamicin. Although bacterial canker is an important disease of tomato in KPK, no significant amount of research work has been on this disease so far. As the use of antibiotics as tomato transplant dip could be easily integrated in $\mathrm{Cmm}$ integrated disease management (IDM) package, therefore we were interested in investigating the role of these chemicals in $\mathrm{Cmm}$ management. The research was carried out to test the efficacy of different antibiotics on the inhibition of 
the in-vitro growth of $\mathrm{Cmm}$ and to investigate the effect of selected antibiotics on the control of bacterial canker under screen-house condition.

\section{Materials and methods}

Source of bacterial culture and pathogenicity test

Already identified polymerase Chain Reaction (PCR) culture of Clavibacter michiganense subsp. michiganenses $(\mathrm{Cmm})$ was obtained from the culture bank of the Department of Plant Pathology, The University of Agriculture Peshawar. For the confirmation of $\mathrm{Cmm}$ pathogen, pathogenicity test was carried out. Bacterial suspension, having $10^{9} \mathrm{cfu} / \mathrm{ml}$, was prepared from 2 days old bacterial culture. Thirty day old seedlings were transplanted into earthen pots having pore at bottom (to facilitate air exchange and avoid water accumulation) and were injected using hypodermic medical syringe at crown region of tomato plant. Shoot(s) and leaves showed downward turning (wilting) indicated a systemic infection. Bacterial pathogen was reisolated from wilted shoot on YDM medium and identified as $\mathrm{Cmm}$.

\section{In-Vitro antibacterial efficacy of antibiotics}

A total of three antibiotics and their combinations viz streptomycin, tetracycline and gentamicin were tested for their ability to retard the growth (produce inhibition zones) of the bacterium $(\mathrm{Cmm})$ on PDA under in vitro conditions [11] . Each antibiotic was tested at 8 different concentration levels (50 ppm, 100 ppm, 150 ppm, 200 ppm, 250 ppm, 300 ppm, 350 ppm, $400 \mathrm{ppm}$ ). Two factors (antibiotics and their concentrations) in CRD, five replicates and one paper disc $(6 \mathrm{~mm})$ per treatment per replicate was used. For testing the antibacterial efficacy of different antibiotics and their concentrations paper disc diffusion method (PDM) was applied [12] . Bacterial lawn was first prepared on by spreading bacterial suspension (approximately $10^{9}$ $\mathrm{cfu} / \mathrm{ml})$ on PDA (100 ul/plate) by sterile bent rod. These plates were then used for invitro tests involving bacterial growth inhibition by different antibiotics. Sterilized filter paper discs (6 mm, Advantec Tokyo , Tokyo Roshi Kaisha Ltd, Japan) were soaked in each ppm of antibiotics solutions for 15-20min, dried and then placed aseptically on pre-inoculated (for the production of bacterial lawn) PDA plates. Almost 10ul antibiotic concentration was absorbed by each disc. Disc soaked in sterile distilled water served as negative control. Plates were incubated at $28+20 \mathrm{C}$. The bacterial inhibition zones $(\mathrm{mm})$ around different discs were recorded after 24 and 48 hrs.

In-Vivo antibacterial efficacy of antibiotics and copper fungicide

Total 8 treatments and 3 concentrations (200 ppm, $250 \mathrm{ppm}$ and $400 \mathrm{ppm}$ ) were used in screen house experiment. T1=Tetracycline, T2=Streptomycin, T3=Tetracycline + streptomycin, T4=Streptomycin+ copper oxychloride (COC), T5=Tetracycline+ copper oxychloride (COC), T6=Tetracycline+ Streptomycin + copper oxychloride $\quad$ (COC), $\mathrm{T} 7=$ Copper oxychloride (COC) and $\mathrm{T} 8=$ Control (sterilized distilled water).Tomato variety used was Rio Grande. Tomato nursery was raised in earthen plates filled with chemically sterilized soil (deconil @ 2g/kg). About 3 weeks old tomato seedling (one plant/pot) were transplanted into pots (12 inches, diameter) having chemically sterilized soil. Antibiotics and their concentration (ppm) that gave promising results in in-vitro tests (tetracycline and streptomycin), copper fungicide (Copper oxychloride) and their combinations were tested for their effect against $\mathrm{Cmm}$ under screen house conditions. Plants were sprayinoculated as well as leaf clip- inoculated by using contaminated scissors. Inoculated 
plants without antibiotics were included as a control. Experiment was arranged in two factors factorial experiment in CRD layouts with five replicates per treatment in screen house. Plants were uprooted after termination of experiment and data on disease severity, yield and yield parameters were taken after two months of inoculation.

\section{Inoculation of plants}

Bacterial culture grown over night on LB was scrapped off of plates and suspended in $0.85 \%$ saline $(\mathrm{NaCl})$ solution or sterilized distilled water. Concentration was adjusted to $10^{9} \mathrm{cfu} / \mathrm{ml}$ using spectrophotometer, $\mathrm{OD}_{600}=1.0[13]$. Bacterial suspension was sprayed by using common sprayer on tomato transplant at surface run-off level.The selected antibiotics and their different concentrations (ppm) were also applied to inoculated plants by using spray method. Copper is a contact fungicide so it was sprayed before inoculation of tomato plants. Water was used as a negative control. All other antibiotics and their combinations were applied after inoculation. Four sprays were done with the intervals of 15 days.

\section{Data parameters and statistical analyses}

Data on disease severity was recorded at the interval of 15 days and total 4 sprays were done. Disease severity was recorded on each plant according to the scale of [14] i.e. $0=$ No disease (healthy plant no symptoms), $1=$ Less than $50 \%$ of the plant had symptoms (wilting, chlorosis of lower leaves and brown spots on leave), $2=$ More the $50 \%$ of the plant had symptoms (wilting, chlorosis of upper leaves and lower leaves, marginal necrosis and canker), 3 = Plant completely dead. Disease severity was converted to $\%$ by using the formula [15]. $\mathrm{S}=\sum \mathrm{n} / 3 \mathrm{~N}$, where $\mathrm{S}=$ severity $(\%)$, $\sum \mathrm{n}=$ summation of individual rating, $3=$ highest scale and $\mathrm{N}=$ total no. of plants/leaves. Yield per plant (g) was recorded by taking four pickings from each tomato plant. Weight of all fruit per plant was measured. In screen house height in $\mathrm{cm}$ of individual plant was measured after 60 days of transplantation. Numbers of shoots were also measured from ground to upward of each plant after 60 days of transplantation. After termination of experiment plants were uprooted, washed and plant fresh weight (g), plant dry weight (g) and dry root weight (g) of individual plant was recorded by using electric balance. In case of plant and root dry weight they were dried under sunlight for 10 days. Data were analyzed by using statistix software 8.1. CRD design with 2 factorial arrangements was used. Difference between the treatments was found by using Fisher's protected Least Significant Difference test (LSD) at $\mathrm{P}<0.05$.

\section{Results}

In-Vitro Antibacterial Efficacy of Different Antibiotics against Bacterial Canker of Tomato

Different antibiotics and their concentrations were evaluated for their ability to inhibit the in-vitro growth of $\mathrm{Cmm}$. Antibiotics and their concentrations significantly $(\mathrm{P}<0.05)$ retarded the growth of $\mathrm{Cmm}$. The largest inhibition zone was produced by tetracycline+streptomycin $\quad(22.8 \mathrm{~mm})$ followed by tetracycline $(22.0 \mathrm{~mm})$ and streptomycin+gentamicin $(21.20 \mathrm{~mm})$ at 400ppm. Smallest inhibition zone was produced by streptomycin with $11.10 \mathrm{~mm}$ at $400 \mathrm{ppm}$. All antibiotics showed progressive increase as concentrations increased from 50 ppm to $400 \mathrm{ppm}$. Although streptomycin showed less effective results but when streptomycin was used in combination with tetracycline, it gave good results. Combination of streptomycin with gentamicin also gave significant results. However, because of being expensive gentamicin was dropped. 


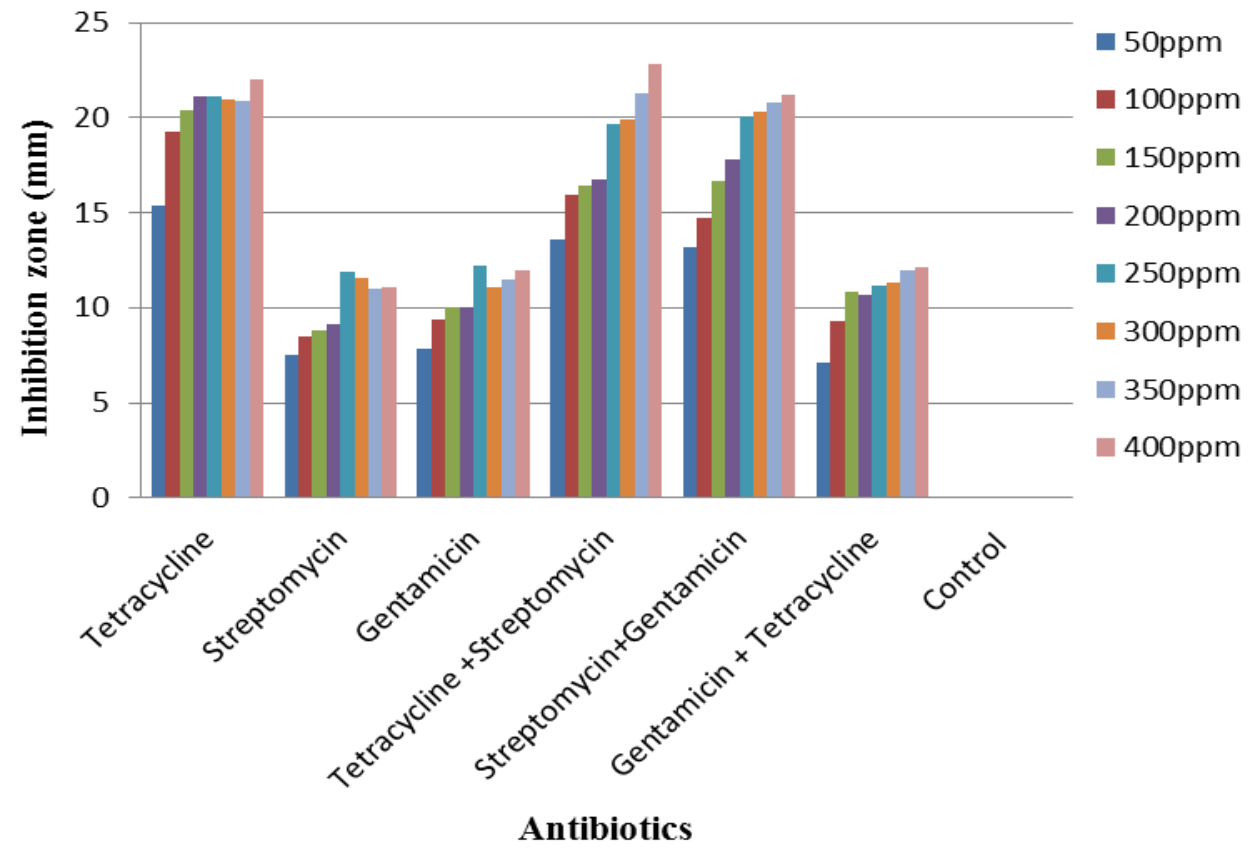

Figure 1. Effect of different antibiotics and their concentrations on the in vitro inhibition of Clavibacter michiganensis subsp. michiganensis $(\mathrm{Cmm}) 48 \mathrm{hrs}$ after incubation at $28 \pm 2^{\circ} \mathrm{C}$

Effect of antibiotics and copper fungicide on tomato plants inoculated with $\mathrm{Cmm}$ under screen-house studies

Antibiotics, $\mathrm{Cu}$ fungicide (copper oxychloride) and their interaction significantly $(\mathrm{P}<0.05)$ affected disease severity of tomato plants inoculated with Cmm (Table 1). All the antibiotics and their concentrations reduced the $\%$ disease severity. Antibiotics which were used in combination with copper oxychloride (COC) gave better results in comparison to their use alone. Plants treated with Tetracycline+COC $(5.4 \%)$ and tetracycline+ streptomycin+COC (5.9\%) had minimum \% disease severity at the highest concentration. Control treatment showed maximum \% disease severity.

Application of antibiotics, $\mathrm{Cu}$ fungicide and their concentrations caused an increase in plant height of tomato plants by reducing the disease (Table 1). Antibiotics and their concentrations were significantly different from each other and also from control.
Maximum height was observed in case of tetracycline+COC $(102.0 \mathrm{~cm})$ followed by tetracycline+streptomycine+COC $(93.0 \mathrm{~cm})$ at $400 \mathrm{ppm}$. The interaction between the antibiotics, COC and their concentrations showed the greatest increase in fresh plant weight (Table 1). Tetracycline+COC at concentration $400 \mathrm{ppm}$ gave the maximum weight (491.1g) and minimum weight was recorded for COC (117.43g) at $200 \mathrm{ppm}$. Lowest weight was recorded for control with mean value $106.67 \mathrm{~g}$.

All treatments at all concentrations i.e. 200 ppm, $250 \mathrm{ppm}$ and $400 \mathrm{ppm}$ increased yield plant-1. Best yield (1147.7g) was produced by tetracycline+COC at $400 \mathrm{ppm}$, followed by tetracycline+streptomycin+COC $(1087.7 \mathrm{~g})$ at concentration $400 \mathrm{ppm}$ and tetracycline+COC (1086g) at $250 \mathrm{ppm}$. Lowest yield was produced by COC $(559.3 \mathrm{~g})$ at $200 \mathrm{ppm}$ and streptomycin $(599.7 \mathrm{~g})$ at $200 \mathrm{ppm}$. Yield in case of control was $283.3 \mathrm{~g}$. Results on dry plant weight (Table 4.12) indicated significant 
effect $\quad(\mathrm{P}<0.05)$ of antibiotics and concentrations. Maximum plant dry weight was recorded from interaction tetracycline+COC $(130.8 \mathrm{~g})$ at $400 \mathrm{ppm}$.
Minimum plant dry weight $(32.3 \mathrm{~g})$ was produced by $\mathrm{COC}$ at $200 \mathrm{ppm}$. As concentration increased, plant dry weights were also increased.

Table 1. Effect of antibiotics and copper fungicide on disease severity, plant growth and yield of tomato plants inoculated with $\mathrm{Cmm}$ under screen-house studies

\begin{tabular}{|c|c|c|c|c|c|c|}
\hline Treatments & $\begin{array}{c}\text { Concentration } \\
(\mathbf{p p m})\end{array}$ & $\begin{array}{c}\text { Disease } \\
\text { severity } \\
(\%)\end{array}$ & $\begin{array}{c}\text { Plant } \\
\text { height } \\
\text { (cm) }\end{array}$ & $\begin{array}{c}\text { Fresh } \\
\text { weight }(\mathrm{g})\end{array}$ & $\begin{array}{c}\text { Yield/ } \\
\text { plant (g) }\end{array}$ & $\begin{array}{c}\text { Dry } \\
\text { weight } \\
(\text { g) }\end{array}$ \\
\hline \multirow[t]{3}{*}{ Tetracycline } & 200 & $11.60 \mathrm{~d}$ & $66.00 \mathrm{e}$ & $167.3 \mathrm{ij}$ & $714.7 \mathrm{k}$ & $42.67 \mathrm{ki}$ \\
\hline & 250 & $10.97 \mathrm{ef}$ & $70.67 \mathrm{~cd}$ & $230.3 \mathrm{gh}$ & $767.3 \mathrm{ij}$ & $53.33 \mathrm{jk}$ \\
\hline & 400 & $10.23 \mathrm{ef}$ & $74.33 \mathrm{~cd}$ & $344.00 \mathrm{f}$ & $832.7 \mathrm{gh}$ & $68.33 \mathrm{hi}$ \\
\hline \multirow[t]{3}{*}{ Streptomycin } & 200 & $13.60 \mathrm{c}$ & $60.67 f$ & $133.3 \mathrm{jkl}$ & $599.7 \mathrm{mn}$ & 36.331 \\
\hline & 250 & $11.67 \mathrm{~d}$ & $64.67 \mathrm{ef}$ & $164.8 \mathrm{ijk}$ & $644.0 \mathrm{~lm}$ & 40.671 \\
\hline & 400 & 10.50 def & $70.50 \mathrm{~d}$ & $267.87 \mathrm{~g}$ & $709.3 \mathrm{k}$ & $65.00 \mathrm{hi}$ \\
\hline \multirow[t]{3}{*}{ Tetracycl +Stepto } & 200 & $11.73 \mathrm{~d}$ & $66.67 \mathrm{e}$ & $202.0 \mathrm{hi}$ & $761.3 \mathrm{ijk}$ & $60.00 \mathrm{ij}$ \\
\hline & 250 & $10.70 \mathrm{def}$ & 69.67ed & $266.30 \mathrm{~g}$ & $806.0 \mathrm{hi}$ & $68.00 \mathrm{hi}$ \\
\hline & 400 & $9.57 \mathrm{fg}$ & $75.33 c$ & $335.90 \mathrm{f}$ & $875.7 \mathrm{fg}$ & $74.6 \mathrm{gh}$ \\
\hline \multirow[t]{3}{*}{ Streptomycin+COC } & 200 & $10.17 \mathrm{ef}$ & $76.50 \mathrm{c}$ & $359.8 \mathrm{ef}$ & $809.7 \mathrm{hi}$ & $83.67 \mathrm{fg}$ \\
\hline & 250 & $8.63 \mathrm{gh}$ & $81.17 \mathrm{~b}$ & $376.0 \mathrm{def}$ & $913 \mathrm{ef}$ & $96.67 \mathrm{de}$ \\
\hline & 400 & 8.43 ghi & $79.67 \mathrm{bc}$ & 389.6 cde & $944.7 \mathrm{de}$ & $91.67 \mathrm{ef}$ \\
\hline \multirow[t]{3}{*}{ Tetracycline+COC } & 200 & $7.30 \mathrm{hij}$ & $90.00 \mathrm{a}$ & $413.8 \mathrm{bcd}$ & $1026.3 \mathrm{c}$ & $112.5 \mathrm{bc}$ \\
\hline & 250 & $6.87 \mathrm{ik}$ & $92.33 a$ & $436.50 \mathrm{~b}$ & $1086 \mathrm{~b}$ & $116.6 \mathrm{~b}$ \\
\hline & 400 & 5.401 & $102.00 \mathrm{a}$ & $491.17 \mathrm{a}$ & $1147.7 \mathrm{a}$ & $130.8 \mathrm{a}$ \\
\hline \multirow[t]{3}{*}{$\begin{array}{l}\text { Tetracycl+Strept } \\
\text { +COC } \\
\end{array}$} & 200 & 8.20 hij & $84.67 b$ & $392.37 \mathrm{bcd}$ & $972.7 \mathrm{~d}$ & $105.4 \mathrm{~cd}$ \\
\hline & 250 & $7.10 \mathrm{ijk}$ & $90.33 a$ & $408.13 \mathrm{bcd}$ & $1028.7 \mathrm{c}$ & $106.2 \mathrm{bcd}$ \\
\hline & 400 & $5.90 \mathrm{kl}$ & $93.00 \mathrm{a}$ & $428.53 \mathrm{bc}$ & $1087.7 \mathrm{~b}$ & $115.0 \mathrm{bc}$ \\
\hline \multirow{3}{*}{$\mathrm{COC}$} & 200 & $16.63 \mathrm{~b}$ & $56.67 \mathrm{~g}$ & 117.431 & $559.3 \mathrm{n}$ & $32.33 \mathrm{~lm}$ \\
\hline & 250 & $14.70 \mathrm{c}$ & $60.00 \mathrm{f}$ & $122.27 \mathrm{kl}$ & 655.01 & $33.33 \mathrm{~lm}$ \\
\hline & 400 & $11.23 \mathrm{de}$ & $65.67 \mathrm{e}$ & $129.57 \mathrm{jkl}$ & $746.3 \mathrm{jk}$ & 35.001 \\
\hline Control & & $56.67 \mathrm{a}$ & $54.67 \mathrm{~g}$ & 106.671 & $283.3 \mathrm{o}$ & $22.67 \mathrm{~m}$ \\
\hline
\end{tabular}

Means in a column followed by the same letter(s) do not differ significantly at $5 \%$ level of significance. Each value is a mean of five replicates

\section{Discussion}

Bacterial diseases of plants are very difficult to control. Bacterial canker of tomato is notoriously hard-to-manage disease because the pathogen hides in the plant host's vascular tissue making it impractical to be eradicated by applying a pesticide to the plants surface. Moreover under favorable conditions, bacterial population can double several times daily, resulting in devastating 
financial losses to farmers. Integrated disease management (IDM) strategies are the only way to control such hard-to-control disease as bacterial canker of tomato caused by Clavibacter michiganenses subp. michiganenses (Cmm). IDM approach could include the use of host resistance, sanitation, different cultural practices and the limited use of chemicals such as antibiotics and copper compounds.

The aim of the present study was to investigate the use of antibiotics and copper oxychloride, alone and in combinations, as a component of the integrated disease management of the bacterial canker of tomato. Streptomycin has been the antibiotic of choice for the control of many bacterial diseases as it is bactericidal and kills the pathogen. Tetracycline which is bacteriostatic .i.e. it stops the growth of bacteria but does not kill the existing population, is less effective than streptomycin but is still used for the control of plant bacterial diseases [16-19]. The most commonly used non-antibiotic bactericides include copper compounds, either alone or mixed with mancozeb. These bactericides could be applied preventively before the appearance of symptoms or after symptoms have appeared [20].

The results of this study indicated that some treatment i.e. tretracycline+copper oxychloride,

tetracycline+streptomycin+copper

oxychloride and tetracycline alone significantly reduced disease severity and increased growth and yield parameters. Our results are in line with those of $[20,8]$. Streptomycin is an aminoglycoside bactericidal antibiotic which targets the bacterial ribosome. This antibiotic irreversibly binds to ribosomal protein and interferes with the movement of the ribosome along the mRNA. As a consequence, streptomycin makes protein synthesis less accurate or blocks the synthesis of protein [21-23]. Tetracycline (oxytetracycline) on the other hand, reversibly binds to bacterial ribosome and interferes with the loaded tRNA (containing an amino acid) coming into the ribosome. As a result, protein synthesis remains blocked for as long as the antibiotic is bound to the ribosome [16].

Long term use of bactericides, as expected, may lead to the appearance of antibioticresistance strains. Therefore, plant bacterial management programs that are not wholly dependent on bactericides are desirable [8]. Streptomycin resistance has been found to occur in plant pathogens but no tetracyclineresistance plant pathogenic bacteria have been reported yet [24]. Two mechanisms for resistance to streptomycin have been reported in antibiotic-resistant strains. The most common mechanism is the spontaneous mutation of the chromosomal gene rpsl, which encodes the production of ribosomal protein. As a result of this mutation, streptomycin is un-able to bind to the mutated ribosomal protein. The second mechanism involves the inactivation of streptomycin by bacterial phosphotransferase, an enzyme produced by strA and strB gene. The genes strA and strB usually reside on mobile genetic elements (transposons) and have been identified in at least 17 environmental and clinical bacteria populating diverse niches. This explains why streptomycin resistance is so frequent in plant pathogen $[21,22]$.

In order to discourage or delay the development of antibiotic-resistance in plant pathogens, antibiotics are used in combinations with each other as well as copper oxychloride or other coppercontaining chemicals. The results of our study indicated that disease severity was significantly reduced and yield and yield parameters were improved when bactericides were used in combinations. It is quite common and easy for plant pathogenic 
bacteria to have point mutations and develop resistance against antibiotics when they are used alone over a period of time. However, in order to develop resistance against more than one chemical (used in combination) bacteria have to develop multiple mutations at the same time which is not easy.

\section{Conclusion}

In our study some of the antibiotic concentrations proved to be very significant in terms of reducing \% disease severity of bacterial canker of tomato and enhancing yield and yield parameters. However, these combinations were used only as sprays. The effective combination i.e. tetracycline+copper oxychloride and tetracycline+streptomycin+copper

oxychloride should be investigated for their use as transplant-dip and seed-dip. And, if found effective, should be included in the integrated disease management for bacterial canker of tomato.

\section{Authors' contributions}

Conceived and designed the experiments: $\mathrm{M}$ Ahmad \& A Khalid, Performed the experiments: A Khalid, RAA Khan \& I Naz, Analyzed the data: A Ali \& SS Alam, Contributed materials/ analysis/tools: A Ali \& SS Alam, Wrote the paper: A Khalid, RA A Khan \& M Ahmad.

\section{References}

1. Felix ED \& Mahendran T (2009). Physico-chemical properties of mature green tomatoes (Lycopersicon Esculentum) coated with pectin during storage and ripening. J Trop Agri Res \& Ext 12(2): 110-112

2. Naika S, Lidt de Jeude J, de Goffau M, Hilmi M \& Van Dam B (2005). Cultivation of tomato production, processing and marketing. CTA. Series No 17.

3. Agrawal K, Sharma DK \& Jain KV, (2012). Seed-borne bacterial diseases of tomato (Lycopersicon Esculentum Mill.) and their control measures. Inter J Food Agri Vet Sci 2 (2): 173-182

4. Murtaza N \& Donald LS 2009. Final progress report, Macdonald campus of McGill University Quebec, Canada.

5. Tobias AJ, Lehoczki-Tornai Z, Szalai L, Csambalik L \& Radics L (2007). Effect of different treatments to bacterial canker (Clavibacter michiganensis subsp. michiganensis), bacterial speck (Pseudomonas syringae pv. tomato) in tomato, and bacterial spot (Xanthomonas campestris pv. vesicatoria) in pepper. Inter J of Horti Sci 13 (2): 49-53.

6. Bose TK, Kabir J, Maity TK, Parthasarathy VA \& Som MG (2004). Vegetable crops (vol. I edt). Naya Prakash, Kolkatta 987.

7. Jahr H, Bahro R, Burger A, Ahlemeyer J \& Eichenlaub R (1999). Interactions between Clavibacter michiganensis and its host plants. Env Microbiol 1: 113118.

8. Werner NA, Fulbright DW, Podolsky R, Bel J \& Hausbeck MK (2002). Limiting Populations and Spread of Clavibacter michiganensis subsp. michiganensis on Seedling Tomatoes in the Greenhouse. $J$ Amer Phytopathol Soc 8(5): 535-542.

9. Quesada-Ocampo, LM, Landers NA, Lebeis AC, Fulbright DW \& Hausbeck MK (2012). Genetic Structure of Clavibacter michiganensis subsp. michiganensis populations in Michigan commercial tomato fields. $J$ Amer Phytopathol Soc 96(6): 788-796

10. Waksman SA (1952). Streptomycin. Nature and practical applications, pp. ix + 618 pp. Record no. 19501100729.

11. Gavin JJ (1956). Microbiological process report II. The diffusion methods, Analy Microbiol 2(5): 25-33.

12. Popovic T, Milicevic Z, Milovanovic P, Dolovac N \& Ivanovic Z (2013). Copper-Citrate as a Possibility for 
Control of Some Phytopathogenic Bacteria. Athens: Atiner's Conference Paper Series, No: AGR 0767.

13. Brown DG, Swanson JK \& Allen C (2007). Two Host-Induced Ralstonia solanacearum Genes, acrA and dinF, Encode Multidrug Efflux Pumps and Contribute to Bacterial Wilt Virulence. Appl Environ Microbiol 73(9): $2777-$ 2786.

14. Wright PJ \& Koolaard J (2005). Growing methods and chemical control drenches control calla soft rot. Acta Horticulture (ISHS) 673: 769-774.

15. Bdliya BS \& Dahiru B (2006). Efficacy of some plant extracts on the control of potato tuber soft rot caused by Erwinia carotovora subsp. carotovora. J Plant Prot Res 46 (3): 285-294.

16. McManus P \& Stockwell V (2000). Antibiotics for Plant Diseases Control: Silver Bullets or Rusty Sabers. APSnet Features. Online. doi: 10.1094/APSnetFeature-2000-0600.

17. McManus PS, Stockwell VO, Sundin GW \& Jones AL (2002). Antibiotic use in plant agriculture. Phytopathol 40: 443-465.

18. Christiana RSC, Reilly CC, Miller WP \& Scherm H (2010). Oxytetracycline dynamics on peach leaves in relation to temperature, sunlight, and simulated rain. Plant Dis 94: 1213-1218.
19. Stockwell VO \& Duffy B (2012). Use of antibiotics in plant agriculture. 31(1): 199-210.

20. Hausbeck MK, Bell J, Medina-Mora C, Podolsky R \& Fulbright DW (2000). Effect of bactericides on population sizes and spread of Clavibacter michiganensis subsp. michiganensis on tomatoes in the greenhouse and on disease development and crop yield in the field. Phytopathol 90: 38-44.

21. Chiou CS \& Jones AL (1995). Molecular analysis of high-level streptomycin resistance in Erwinia amylovora. Phytopathol 85: 324-328.

22. Jones AL \& Schnabel EL (2000). The development of streptomycin-resistant strains of Erwinia amylovora, in fire blight the disease and its causative agent, Erwinia amylovora (J. Vanneste, ed.). CAB International, Wallingford, UK, pp. 235-251.

23. O'Neil MJ (2006). The Merck Index an encyclopedia of chemicals, drugs, and biologicals (14th Ed.). Merck, Whitehouse Station, NJ.

24. Palmer EL, Teviotdale BL \& Jones AL (1997). A relative of the broad-hostrange plasmid RSF1010 detected in Erwinia amylovora. Appl Environ Microbiol 63: 4604-4607. 